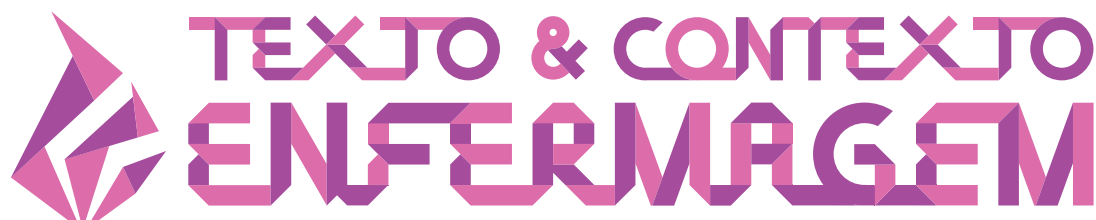

TEXT \& CONTEXT NURSING TEXTO \& CONTEXTO ENFERMERÍA

\section{COVID-19 AND DIGITAL TECHNOLOGY: MOBILE APPLICATIONS AVAILABLE FOR DOWNLOAD IN SMARTPHONES}

\author{
Nelson Miguel Galindo Neto ${ }^{1}$ (C) \\ Guilherme Guarino de Moura Sá ${ }^{2}$ (1) \\ Luciana Uchôa Barbosa ${ }^{2}$ (D) \\ Juliana de Castro Nunes Pereira ${ }^{2}$ (1) \\ Amanda Haissa Barros Henriques ${ }^{3}$ (D) \\ Lívia Moreira Barros 4 (D)
}

\begin{abstract}
${ }^{1}$ Instituto Federal de Educação, Ciência e Tecnologia de Pernambuco, Campus Pesqueira. Pesqueira, Pernambuco, Brasil. ${ }^{2}$ Instituto Federal de Educação, Ciência e Tecnologia de Pernambuco, Campus Belo Jardim. Belo Jardim, Pernambuco, Brasil. 3Instituto Federal de Educação, Ciência e Tecnologia da Paraíba, Campus Mangabeira. João Pessoa, Paraíba, Brasil.

${ }^{4}$ Universidade da Integração Internacional da Lusofonia Afro-Brasileira, Campus das Auroras. Redenção, Ceará, Brasil.
\end{abstract}

\begin{abstract}
Objective: to describe Covid-19 mobile applications available for download on smartphones.

Method: a cross-sectional study with 52 mobile applications on Covid-19, obtained from virtual stores for smartphones with Android and iOS operating systems. Fisher's exact test and Cramér's V were used.

Results: of the applications, 45 (86.6\%) were developed in 2020, 51 (98.1\%) were free, and 49 (94.2\%) did not have accessibility for people with disabilities. It was observed that, in 23 countries, 17 (32.7\%) applications in English and 14 (26.9\%) in Portuguese were created, with a choice of 11 languages, relating to nine subthemes on Covid-19, the majority on "case monitoring" and "symptoms, prevention, and care", with 17 (32.7\%) each. There was an association between the target audience and the subtheme of "symptoms, prevention, and care", and between patient monitoring and professional training.

Conclusion: Covid-19 mobile applications were available in countries on five continents, in the main languages of communication and free of charge; however, with limited accessibility for people with disabilities.
\end{abstract}

DESCRIPTORS: Coronavirus. Technology. Mobile applications. Smartphone. Health education. 


\section{COVID-19 E TECNOLOGIA DIGITAL: APLICATIVOS MÓVEIS DISPONÍVEIS PARA DOWNLOAD EM SMARTPHONES}

\section{RESUMO}

Objetivo: descrever aplicativos móveis sobre Covid-19 disponíveis para download em smartphones.

Método: estudo transversal com 52 aplicativos móveis sobre Covid-19, obtidos nas lojas virtuais para smartphones com sistema operacional Android e iOS. Utilizou-se o Teste Exato de Fisher e $V$ de Cramér.

Resultados: dos aplicativos, $45(86,6 \%)$ foram desenvolvidos em 2020, 51 (98,1\%) eram gratuitos e 49 $(94,2 \%)$ não possuíam acessibilidade para pessoas com deficiência. Observou-se que foram criados, em 23 países - $17(32,7 \%)$ em inglês e $14(26,9 \%)$ em português, com opção de 11 idiomas, aplicativos referentes a nove subtemas sobre a Covid-19, a maioria sobre "monitoramento de casos" e "sintomas, prevenção e cuidados", com $17(32,7 \%)$ cada. Ocorreu associação entre o público-alvo e o subtema "sintomas, prevenção e cuidados", e entre monitoramento de pacientes e capacitação profissional.

Conclusão: os aplicativos móveis sobre Covid-19 encontravam-se disponíveis em países dos cinco continentes, nos principais idiomas de comunicação, de forma gratuita, entretanto, com escassa acessibilidade para pessoas com deficiência.

DESCRITORES: Coronavírus. Tecnologia. Aplicativos móveis. Smartphone. Educação em saúde.

\section{COVID-19 Y LA TECNOLOGÍA DIGITAL: APLICACIONES MÓVILES DISPONIBLES PARA DESCARGAR EN TELÉFONOS INTELIGENTES}

\section{RESUMEN}

Objetivo: describir aplicaciones móviles sobre Covid-19 disponibles para descargar en teléfonos inteligentes. Método: estudio transversal realizado con 52 aplicaciones móviles sobre Covid-19 obtenidas en las tiendas virtuales para teléfonos inteligentes con sistemas operativos Android e iOS. Se emplearon la Prueba Exacta de Fisher y el coeficiente $V$ de Cramér.

Resultados: del total de aplicaciones, $45(86,6 \%)$ fueron desarrolladas en el año 2020, $51(98,1 \%)$ eran gratuitas, y 49 (94,2\%) no ofrecían accesibilidad para personas con discapacidades. Se observó que, en 23 países, se diseñaron diversas aplicaciones, $17(32,7 \%)$ en inglés y $14(26,9 \%)$ en portugués, con opción de 11 idiomas, relacionadas con nueve subtemas sobre Covid-19. La mayoría sobre "monitorización de casos" y sobre "síntomas, prevención y cuidados", con 17 (32,7\%) aplicaciones en cada subtema. Se registró una asociación entre el público objetivo y el subtema de "síntomas, prevención y cuidados", y también entre la monitorización de pacientes y la capacitación profesional.

Conclusión: se registró disponibilidad de aplicaciones móviles sobre Covid-19 en países de los cinco continentes, en los principales idiomas de comunicación, y en forma gratuita; no obstante, con accesibilidad limitada para personas con discapacidades.

DESCRIPTORES: Coronavirus. Tecnología. Aplicaciones móviles. Teléfono inteligente. Educación en salud. 


\section{INTRODUCTION}

Covid-19 is a disease caused by the SARS-CoV-2 coronavirus, initially identified in 2019 in the Chinese city of Wuhan. Given its high transmissibility and rapid spread, in 2020 it became a public health emergency of international interest. ${ }^{1}$ This disease can cause fever, dry cough, fatigue, dyspnea, malaise, and myalgia. Older adults, pregnant women, immuno-suppressed individuals and those with comorbidities such as diabetes and cardiovascular diseases can develop more severe forms of the disease. ${ }^{2}$

According to data from the World Health Organization (WHO), in the world, in May 2020,4,618,821 cases had been recorded, with 311,847 deaths. ${ }^{3}$ In order to delay/interrupt the chain of disease transmission, the health authorities recommend measures for social distancing and the adoption of individual protection habits, such as hand/utensil hygiene and care when coughing or sneezing, in addition to only seeking health care in cases of worsening symptoms related to Covid-19. ${ }^{4}$

Thus, for the population to be educated about appropriate preventive and behavioral measures, access to information emerges as a relevant strategy to face the pandemic. In this scenario, access to the Internet through mobile devices, such as smartphones, has played an important role as a means of searching and obtaining information. ${ }^{5}$

Results of the 2017 National Household Sample Survey (Pesquisa Nacional por Amostra de Domicilios, PNAD), found that $93.2 \%$ of the Brazilian households used smartphones. Of these, $97 \%$ had them as their main means of accessing the Internet, so that the change in behavior in the form of Internet access culminated in the replacement of computers, tablets, smart TVs and other equipment with mobile versions, especially smartphones. ${ }^{5-6}$

Mobile applications, developed especially for these devices, aim to provide information to people, without time and space restrictions. ${ }^{7}$ There is an increase in the availability of this digital technology, which has collaborated in the construction of new models of health care. ${ }^{8}$ Such technologies, when focused on the health area, provide tools that assist in the communication, structuring, and organization of data and information. In addition, they enable data storage, processing, real-time and/or remote access and sharing, either by the professionals involved in the care or by the patients themselves. ${ }^{9}$

Among the health professional categories, Nursing benefits from the use of applications, since they can assist in the assessment and decision making in order to eliminate data repetition and to improve communication. ${ }^{10}$ This contributes to the implementation of preventive actions, survey of diagnostic information, and time optimization in care and management activities. ${ }^{11}$

In the Covid-19 pandemic scenario, emerging mobile applications can become instruments for monitoring information and encouraging self-care for people in social isolation, in addition to being a resource to be used by health professionals. In this sense, the description of existing applications on the subject can contribute to the perception of which application profiles present lack of construction, which information is missing from existing applications, and for which types of audience they are targeted. Thus, it allows identifying gaps that need to be filled, through the development of new applications.

This study arises from the absence of investigations describing Covid-19 mobile applications available for smartphones. Thus, it is intended to contribute to the state of the art and the expansion of knowledge in the face of the pandemic.

In view of this, this study aimed to describe mobile applications on Covid-19 available for download on smartphones. 


\section{METHOD}

A cross-sectional study conducted in April 2020, from an online search in virtual stores of mobile applications for smartphones with Android and iOS operating systems. Thus, the applications made available in the referred stores constituted the study population, whose inclusion criterion was to address content on Covid-19. The exclusion criterion adopted was the applications not being available for download, either in a free or paid form. When searching with different terms, applications found in duplicate were counted only once.

To search for mobile applications, the virtual stores were accessed for smartphones with Android and iOS operating systems. In each store, searches were carried out using the terms "Coronavirus" and "Covid-19" individually. All the identified applications were downloaded. Figure 1 shows the flowchart for selecting the applications.

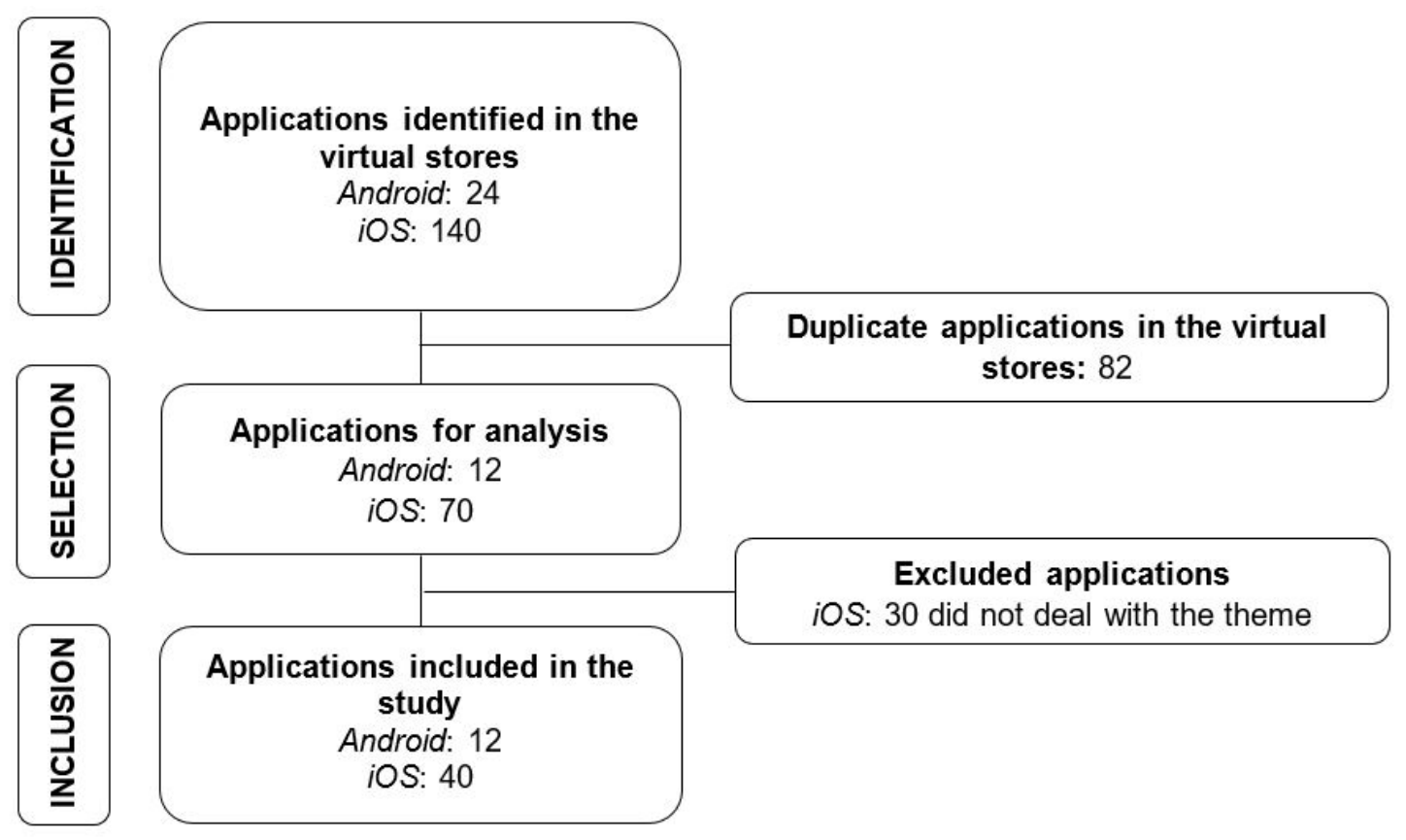

Figure 1 - Fluxogram of the selection process of the applications. Belo Jardim, PE, Brazil, 2020.

It is worth mentioning that the aforementioned searches were carried out simultaneously by two independent researchers, who standardized the sequence of procedures and, after completing the sample recruitment, compared their findings to verify discrepancies in the sample obtained.

For data collection, an instrument developed for this study was used, consisting of 12 variables on the application: operating system; country/state in which it was produced; language; year of creation; year of update in the virtual store; subtheme on Covid-19 which was addressed; indicative classification of content; agency that owns the license to use the application; type of access (open or paid); target audience; and accessibility for people with disabilities. It is noteworthy that these variables were used because they consist of the obtainable information about the applications, available in the application itself and/or in the virtual store.

The data were entered into spreadsheets in the Microsoft Excel 2010 program and then exported to the Statistical Package for the Social Sciences (SPSS), version 21.0. For analysis, descriptive statistics was used, expressed by absolute and relative frequencies. Associations were analyzed using Fischer's Exact test, with a significance level of 5\% and a 95\% confidence interval. Cramér's $V$ coefficient was used to quantify the degree of association between the variables, so that 
$\mathrm{V}<0.1$ indicated a weak association or no association; $0.1 \leq \mathrm{V}<0.3$, a low association; $0.3 \leq \mathrm{V}<0.5$, a moderate association; and $V \geq 0.5$, a strong association. This coefficient is used between two nominal variables that have more than two answer categories..$^{12}$

There was no need for approval by the Research Ethics Committee since the contents analyzed were in the public domain.

\section{RESULTS}

Of the 52 applications included in the sample, eight (15.4\%) were available for the Android operating system, 40 (76.9\%) for iOS, and four (7.7\%) for both systems. With regard to the creation of applications, 45 (86.6\%) were created in 2020. Other applications, developed in previous years, were updated and incorporated the Covid-19 theme in their content. In this sense, one (1.9\%) application was included in each of the following years: 2013, 2016, 2017 and 2018. In three (5.8\%) applications, it was not possible to identify the year of creation. It should be noted that $42(80.8 \%)$ updated the application version in 2020, and ten (19.2\%) did not provide the year in which they were updated.

Table 1 presents characteristics of the applications regarding the type of access, indicative content classification, accessibility for people with disabilities, and available languages.

Table 1 - Characterization of the mobile applications on Covid-19 available for smartphones, according to type of access, indicative content classification, accessibility for people with disabilities, and available languages. Belo Jardim, PE, Brazil, 2020. $(n=52)$

\begin{tabular}{lcc}
\hline Variable & $\mathbf{n}$ & $\mathbf{( \% )}$ \\
\hline Type of access & 51 & $(98.1)$ \\
No fee & 1 & $(1.9)$ \\
For a fee & & \\
Indicative content classification & 30 & $(57.7)$ \\
Free & 14 & $(26.9)$ \\
12 years & 8 & $(15.4)$ \\
17 years & & \\
Accessibility for people with disabilities & 49 & $(94.2)$ \\
No & 3 & $(5.8)$ \\
Yes & & \\
Available languages & 17 & $(32.7)$ \\
English & 14 & $(26.9)$ \\
Portuguese & 10 & $(19.3)$ \\
Spanish & 2 & $(3.9)$ \\
French & 2 & $(3.9)$ \\
Arabic & 1 & $(1.9)$ \\
Portuguese, English, and Spanish & 1 & $(1.9)$ \\
English and Russian & 1 & $(1.9)$ \\
Catalan and Spanish & 1 & $(1.9)$ \\
German & 1 & $(1.9)$ \\
English and Arabic & $1.9)$ \\
Italian & 1 & $(1.9)$ \\
\hline Portuguese, German, French, Chinese, Spanish, Italian, English, and Greek & 1 &
\end{tabular}


Regarding the licenses for disclosure in the virtual store, 16 applications (30.8\%) belonged to a private company; nine (17.3\%) to a State health agency; eight (15.4\%) to a federal health agency; seven (13.5\%) to an international federal agency; six (11.5\%) to a municipal health agency; four $(7.7 \%)$ to non-profit institutions; one $(1.9 \%)$ to a federal financial institution; and one $(1.9 \%)$ to a public university hospital.

The applications dealt with various subthemes on Covid-19, and 41 (78.9\%) were intended for the general public, six (11.5\%) for health professionals and five $(9.6 \%)$ for patients. Table 2 shows the associations about the subthemes addressed and the target audience of the applications.

Table 2 - Association of the subthemes and target audience of Covid-19 mobile applications available for smartphones. Belo Jardim, PE, Brazil, 2020. $(n=52)$

\begin{tabular}{|c|c|c|c|c|c|c|}
\hline \multirow{3}{*}{ Subthemes } & \multicolumn{4}{|c|}{ Target audience } & \multirow{3}{*}{$\mathbf{p}^{*}$} & \multirow{3}{*}{$\mathbf{V}^{\dagger}$} \\
\hline & Patients & $\begin{array}{l}\text { General } \\
\text { public }\end{array}$ & Professionals & Total & & \\
\hline & $\mathrm{n}(\%)$ & $n(\%)$ & $n(\%)$ & $n(\%)$ & & \\
\hline Case monitoring & $3(17.6)$ & $11(64.7)$ & $3(17.6)$ & $17(32.7)$ & 0.217 & 0.246 \\
\hline Symptoms, prevention, and care & - & $17(100.0)$ & - & $17(32.7)$ & 0.031 & 0.361 \\
\hline Health self-monitoring & - & $6(100.0)$ & - & $6(11.6)$ & 1.000 & 0.187 \\
\hline Social isolation monitoring & $1(33.3)$ & $2(66.7)$ & - & $3(5.9)$ & 0.295 & 0.210 \\
\hline Health monitoring & - & $2(100.0)$ & - & $2(3.8)$ & 1.000 & 0.104 \\
\hline Government financial benefit & - & $2(100.0)$ & - & $2(3.8)$ & 1.000 & 0.104 \\
\hline Patients' monitoring & $1(50.0)$ & - & $1(50.0)$ & $2(3.8)$ & 0.041 & 0.388 \\
\hline Professional training & - & - & $2(100.0)$ & $2(3.8)$ & 0.019 & 0.554 \\
\hline Social network for the citizens & - & $1(100.0)$ & - & $1(1.9)$ & 1.000 & 0.073 \\
\hline
\end{tabular}

*Fischer's Exact; †Cramer's V

It was observed that the degree of association between the subthemes of the applications and the target audience varied from weak to strong (Cramer's $\mathrm{V}<0.1$ to $\geq 0.5$ ).

Regarding the country, it was observed that Brazil developed 15 (28.9\%) applications; United States, nine (17.3\%); Spain, three (5.9\%); and Canada, Mexico, Pakistan, and Vietnam, two (3.9\%) each. In addition, one (1.9\%) application was produced by each of the following countries: Africa, Argentina, Armenia, Australia, Bolivia, Chile, Colombia, France, Germany, Guatemala, Italy, Oman, Portugal, Russia, United Arab Emirates, and Uruguay. In one (1.9\%) application it was not possible to identify the country.

Of the 15 applications developed in Brazil, eight were produced at the state level: the states of São Paulo, Paraná, and Rio Grande do Sul produced two (13.3\%) each, and Bahia and Ceará, one (6.7\%) each.

Table 3 describes the subthemes covered in the 15 applications developed in Brazil.

Table 3 - Subthemes covered in Covid-19 mobile applications developed in Brazil and available for smartphones. Belo Jardim, PE, Brazil, 2020. $(n=15)$

\begin{tabular}{lcc}
\hline Subthemes & $\mathbf{n}$ & $\mathbf{( \% )}$ \\
\hline Case monitoring & 5 & $(33.3)$ \\
Health monitoring & 2 & $(13.3)$ \\
Social isolation monitoring & 2 & $(13.3)$ \\
Health self-monitoring & 2 & $(13.3)$ \\
Symptoms, prevention, and care & 2 & $(13.3)$ \\
Social network for the citizens & 1 & $(6.7)$ \\
Government financial benefit & 1 & $(6.7)$ \\
\hline
\end{tabular}




\section{DISCUSSION}

Mobile applications are configured as innovative digital technologies in the face of the Covid-19 epidemiological scenario in the world. In addition to offering convenience and benefits to the population and managers in accessing knowledge, they become an attractive alternative for the continuing education of health professionals by means of visual, tactile, and auditory stimuli.

Most of the Covid-19 mobile applications were available in free versions for smartphones with the iOS operating system. A study carried out in Indonesia found that Android and iOS are the two most popular operating systems among mobile phone users. However, it should be noted that the former is more used, since cell phones with iOS are more expensive, which limits access by the lower middle class population. ${ }^{13}$ In this sense, when considering the reduced number of applications for Android, it becomes necessary to expand the availability of applications for different versions of smartphones, in order to enable the popularization of information through these technologies.

Although the human SARS-CoV-2 coronavirus was first identified in $2019,{ }^{1}$ applications have been found since 2013. This result is justified by the fact that applications, which already existed before Covid-19, with general health information, incorporated this theme in their content through updates. In this perspective, when considering the existence of applications developed by nurses, in the scope of health information, ${ }^{11}$ it is worth suggesting that they carry out updates, which contribute to the spread of care in the pandemic.

The subthemes of Covid-19 addressed by the applications dealt mainly with symptoms of the disease, prevention and care against contamination, in addition to providing monitoring of suspected and confirmed cases. This finding is relevant because, as it is a disease caused by respiratory viruses, whose behavior has not yet been fully clarified, it is urgent to disseminate information quickly and accurately, so that the population can contribute to reducing the spread of the virus and to support rapid interventions by the health institutions. ${ }^{14}$

With regard to the target audience, most of the applications were intended for the general public, without age or profession restrictions. The initiatives aimed at educating the population are ratified by the $\mathrm{WHO}$, as an important strategy for protection against Covid-19. ${ }^{15} \mathrm{It}$ is important to emphasize that the use of digital technology to help the population recognize early symptoms is relevant, as it may enhance the reduction in the demands in the health services by patients with mild symptoms of the disease. ${ }^{16}$ Targeting of health technologies for the general public is found in other Brazilian studies, which emphasize the idea that the use of these technologies contributes to the monitoring and empowerment of the population in health care. ${ }^{17-19}$

When considering the relevance of mobile applications that alert the health teams about suspected or confirmed cases of the disease, and which also provide quick access to occupational safety protocols and patient care, highlights the importance that the results show applications that aimed to help health professionals specifically. The absence of applications with information on case monitoring for professionals can be justified, since they can access information through other sources, such as the service itself. In addition, information on symptoms, prevention, and care is available in most of the applications for the general public, given that the professionals may not prioritize such applications since they already have access to this information.

With regard to accessibility, it was observed that most of the mobile applications on Covid-19 did not have resources for use by people with disabilities, which hinders preserving the right of this public to access information. When considering the epidemiological scenario of the rapid growth in the number of Covid-19 cases in the world, it is urgent to implement mechanisms that guarantee the effectiveness of public policies for social inclusion, in order to stimulate autonomy to search for information. ${ }^{20}$ It is inferred, therefore, that this difficulty may favor the increased vulnerability of this 
population to the disease. Thus, it is pointed out that, when producing applications, Nursing must consider this aspect, and thus contribute to social inclusion through applications that allow for the use by people with disabilities.

Despite being in different languages, the applications listed with information on Covid-19 were mostly available in English, Portuguese, and Spanish. This fact is important, since the availability of applications in different languages favors the wide dissemination of knowledge about diverse aspects of the disease. This result differs from a study that identified mobile applications for the health and care of the older adults, where applications in English prevailed. ${ }^{17}$ The language restriction can limit the benefit of health education and culminate in the low possibility of access and use. Thus, it is pertinent that the applications to be created expand the language possibilities in their formatting, so as to deal with the universalization of their use.

Brazil was the country that developed the largest number of applications on Covid-19, with emphasis on the engagement of state governments in combating the pandemic, with a view, above all, to monitoring cases. This monitoring is relevant, since Brazil has an ascending and rapid characteristic of the epidemic curve in all states of the Federation. ${ }^{21}$ The same strategy was observed in China and Singapore, where studies showed that the government invested in Information and Communication Technologies (ICTs) with the aim of helping to reduce the spread of the disease and to facilitate crisis management during the outbreak period, which contributed to the maintenance of local social order in emergencies. ${ }^{22-23}$ It should be noted that the adoption of individual and collective behavioral measures directly influence the course of the disease. Thus, the implementation of technologies that inform this need becomes relevant. ${ }^{24}$

Due to the limitation of data sources, in this study it was not possible to identify whether the existing applications on Covid-19 were built from scientific studies. In this perspective, it is up to the nurses to develop research studies with a theoretical framework in Nursing science, which contemplate the production of applications for the different dimensions of care for people in social isolation, since this condition is uncommon in recent human history.

As a limitation of this study, the restricted analysis of mobile applications available on the Android and iOS operating systems is pointed out, so that the data found may differ from the applications available on other systems.

\section{CONCLUSION}

For the most part, the Covid-19 mobile applications available for download on smartphones provided free access in countries on the five continents, mainly Brazil, in the main languages of communication, made available by public and private companies. Above all, the applications provided information about symptoms, prevention, and care of the disease, in addition to monitoring cases. A limited number of Covid-19 applications were found for health professionals, as well as poor accessibility for people with disabilities.

The construction of new applications on Covid-19 must therefore be based on the remaining gaps and demands from the public to whom they are intended, in order to make them useful for empowerment and translation of knowledge in health. 


\section{REFERENCES}

1. Morens DM, Daszak P, Taubenberger JK. Escaping Pandora's box-another novel coronavirus. N Engl J Med [Internet]. 2020 [cited 2020 Apr 13];382:1293-5. Available from: https://dx.doi. org/10.1056/NEJMp2002106

2. Ministério da Saúde (BR). Secretaria de Atenção Especializada à Saúde. Departamento de Atenção Hospitalar, Domiciliar e de Urgência. Protocolo de manejo clínico da Covid-19 na Atenção Especializada. 1. ed. rev. Brasília, DF(BR) [Internet]; 2020 [cited 2020 Apr 16]. Available from: https://bvsms.saude.gov.br/bvs/publicacoes/manejo_clinico_covid19_atencao_especializada.pdf

3. World Health Organization. Cononavirus disease (COVID-19) Situation Report - 119. World Health Organization [Internet]; 2020 [cited 2020 May 18]. Available from: https://www.who.int/docs/defaultsource/coronaviruse/situation-reports/20200511-covid-19-sitrep-112.pdf?sfvrsn=813f2669_2

4. Lipsitch M, Swerdlow DL, Finelli L. Defining the epidemiology of Covid-19 - studies needed. N Engl J Med [Internet]. 2020 [cited 2020 Apr 13];382:1194-6. Available from: https://dx.doi. org/10.1056/NEJMp2002125

5. Oliveira ARF, Alencar MSM. The use of health applications for mobile devices as sources of information and education in healthcare. Rev Digit Bibliotecon Cienc Inf [Internet]. 2017 [cited 2020 Apr 14];15:234-245. Available from: https://dx.doi.org/10.20396/rdbci.v0i0.8648137

6. Instituto Brasileiro de Geografia e Estatística. PNAD Contínua TIC 2017: Internet chega a três em cada quatro domicílios do país [Internet]; 2018 [cited 2020 Apr 14]. Available from: https://agenciadenoticias.ibge.gov.br/agencia-sala-de-imprensa/2013-agencia-de-noticias/ releases/23445-pnad-continua-tic-2017-internet-chega-a-tres-em-cada-quatro-domicilios-do-pais

7. Barra DCC, Paim SMS, Sasso GTMD, Colla GW. Methods for developing mobile apps in health: an integrative review of the literature. Texto Contexto Enferm [Internet]. 2017 [cited $2020 \mathrm{Apr}$ 14];26(4):2-12. Available from:https://dx.doi.org/10.1590/0104-07072017002260017

8. Gomes MLS, Rodrigues IR, Moura NS, Bezerra KC, Lopes BB, Texeira JJD, et al. Análisis de aplicaciones móviles para la promoción de la salud de mujeres embarazadas con preeclampsia. Acta Paul. Enferm. [Internet]. 2019 [cited 2020 Apr 14];32(3):275-81. Available from: https:// dx.doi.org/10.1590/1982-0194201900038

9. Roberts S, Chaboyer W, Gonzalez R, Marshall A. Using technology to engage hospitalised patients in their care: a realist review. BMC Health Serv Res [Internet]. 2017 [cited 2020 Apr 15]; 17:388. Available from: https://dx.doi.org/10.1186/s12913-017-2314-0

10. Araujo JL, Sant'anna HC, Lima EFA, Fioresi M, Nascimento LCN, Primo CC. Mobile app for nursing process in a neonatal intensive care unit. Texto Contexto Enferm [Internet]. 2019 [cited 2020 Apr 15];28:e20180210. Available from: $h$ ttps://dx.doi.org/10.1590/1980-265X-TCE-2018-0210

11. Silva AMA, Mascarenhas VHA, Araújo SNM, Machado RS, Santos AMR, Andrade EMLR. Mobile technologies in the nursing area. Rev Bras Enferm [Internet]. 2018 [cited 2020 Apr 15];71(5):25708. Available from: https://dx.doi.org/10.1590/0034-7167-2017-0513

12. Maher JM, Marckey JC, Ebert-May D. The other half of the story: effect size analysis quantitative research. CBE Life Sci Educ [Internet]. 2013 [cited 2020 Apr 15];12(3):345-51. Available from: https://dx.doi.org/10.1187/cbe.13-04-0082

13. Siburian RM, Nuary RP. The difference of iOS and Android usage. Jurnal Darma Agung [Internet]. 2019 [cited 2020 Apr 25];27(2):1057-62. Available from: http://jurnal.darmaagung.ac.id/index. php/jurnaluda/article/view/273

14. Freitas ARR, Napimoga M, Donalisio MR. Assessing the severity of COVID-19. Epidemiol. Serv. Saúde [Internet]. 2020 [cited 2020 Apr 25];29(2):e2020119. Available from: https://dx.doi. org/10.5123/S1679-49742020000200008 
15. World Health Organization. Director-General's opening remarks at the media briefing on COVID-19-5. World Health Organization [Internet]. 2020 [cited 2020 Apr 25]. Available from: https://www.who.int/dg/speeches/detail/who-director-general-s-opening-remarks-at-the-mediabriefing-on-covid-19---5-march-2020

16. Ting DSW, Carin L, Dzau V, Wong TY. Tecnologia digital e COVID-19. Nature Medicine [Internet]. 2020 [cited 2020 Apr 25];26:459-461. Available from: https://doi.org/10.1038/s41591-020-0824-5

17. Amorim DNP, Sampaio LVP; Carvalho GA, Vilaça KHC. Mobile applications for the health and care of elderly. Rev Eletron Comun Inf Inov Saúde [Internet]. 2018 [cited 2020 Apr 25];12(1):5871. Available from: https://dx.doi.org/10.29397/reciis.v12i1.1365

18. Delgado GV, Carvalho RB, Castro JM; Leite RS. Empowerment through health apps: a case study of an application for pregnant women. Rev Adm UNIMEP [Internet]. 2019 [cited 2020 Apr 25];17(1):89-115. Available from: http://www.raunimep.com.br/ojs/index.php/regen/article/ view/1569/783

19. Barra DCC, Almeida SRW, Sasso GTMD, Paese F, Rios GC. Method for the modeling and structuring of computerized nursing in intensive care. Texto Contexto Enferm [Internet]. 2016 [cited 2020 Apr 14];25(3):e2380015. Available from: https://dx.doi.org/10.1590/0104-07072016002380015

20. Galindo-Neto NM, Alexandre ACS, Barros LM, Sá GGM, Carvalho KM, Caetano JÁ. Creation and validation of an educational video for deaf people about cardiopulmonary resuscitation. Rev Latino-Am Enfermagem [Internet]. 2019 [cited 2020 Apr 25];27:e3130. Available from: https:// dx.doi.org/10.1590/1518-8345.2765.3130

21. Ministério da Saúde (BR). Secretaria de Vigilância em Saúde. Boletim epidemiológico No 09. Secretaria de Vigilância em Saúde SVS/MS-COE - Abr [Internet]. 2020 [cited 2020 Apr 25]. Available from: https://portalarquivos.saude.gov.br/images/pdf/2020/april/12/2020-04-11-be9boletim-do-coe.pdf

22. Pan, X. Application of personal-oriented digital technology in preventing transmission of COVID-19, China. Ir J Med Sci [Internet]. 2020 [cited 2020 Apr 25]. Available from: https://dx.doi.org/10.1007/ s11845-020-02215-5

23. Cho H, Ippolito D, Yu YW. Contact Tracing Mobile Apps for COVID-19: Privacy considerations and related trade-offs. ArXiv preprint arXiv [Internet]. 2020 [cited 2020 Apr 25];2003.11511. Available from: https://arxiv.org/abs/2003.11511

24. Oliveira AC, Lucas TC, Iquiapaza RA. What has the covid-19 pandemic taught us about adopting preventive measures? Texto Contexto Enferm [Internet]. 2020 [cited 2020 May 18]:29:e20200106. Available from: https://dx.doi.org/10.1590/1980-265x-tce-2020-0106 


\section{NOTES}

\section{CONTRIBUTION OF AUTHORSHIP}

Study desing: Galindo Neto NM, Sá GGM.

Data collection: Barbosa LU, Pereira JCN.

Data analysis and interpretation: Galindo Neto NM, Sá GGM, Barbosa LU.

Discussion of the results: Sá GGM, Barbosa LU, Barros LM.

Writing and/or critical review of content: Galindo Neto NM, Sá GGM, Barbosa LU, Pereira JCN, Henriques AHB, Barros LM.

Review and final approval of the final version: Galindo Neto NM, Sá GGM, Barbosa LU, Pereira JCN, Henriques AHB, Barros LM.

\section{CONFLICT OF INTERESTS}

There is no conflict of interest.

\section{HISTORICAL}

Received: April 26, 2020.

Approved: May 27, 2020.

CORRESPONDING AUTHOR

Nelson Miguel Galindo Neto

nelsongalindont@hotmail.com 


\section{ERRATUM: COVID-19 AND DIGITAL}

TECHNOLOGY: MOBILE APPLICATIONS

AVAILABLE FOR DOWNLOAD IN

\section{SMARTPHONES}

Regarding the article "COVID-19 AND DIGITAL TECHNOLOGY: MOBILE APPLICATIONS AVAILABLE FOR DOWNLOAD IN SMARTPHONES", with DOI number: https://doi. org/10.1590/1980-265x-tce-2020-0150, published in Texto \& Contexto Enfermagem, vol 29 in 2020, elocation e20200150:

In the author identification Amanda Haissa Barros Henriques, where was written: "http://orcid.org/0000-0003-3484-9179"

Now read: https://orcid.org/0000-0001-8735-225X 